\title{
Observing Social Deference in Two Societies
}

\author{
$1^{\text {st }}$ Majid Wajdi \\ Department of Business Administration \\ Politeknik Negeri Bali \\ Badung, Indonesia \\ mawa2id@gmail.com
}

\author{
$2^{\text {nd }}$ Palus subiyanto \\ Departement of accounting \\ Politeknik Negeri Bali \\ Badung, Indonesia.
}

\author{
$3^{\text {rd }}$ I Made Sumartana \\ Departement of accounting \\ Politeknik Negeri Bali \\ Badung, Indonesia.
}

\begin{abstract}
It is undeniable that the existence of the language of local languages of Indonesia, the language of Java and Bali, cannot be separated from the co-existence of their speech levels, low and high speech levels. These two co-variations, low and high code, enable the speakers to show intimacy, deference, and hierarchy among the members of society in their speech communities. Low and high codes have become codes of communication in these hierarchical societies $[1,2,3]$.

This paper discusses patterns of use of high code in the language of Java and Bali which enables their speakers to show their social deference between or among the participants in a speech event in these social and speech communities of Java and Bali. The symmetrical use of high speech level shows the communication pattern of deference or non-intimate symmetric communication. In non-intimate communication: two speakers use high code to show social marker of deference and it means two members of social societies exercise social distance $(+D)$ but with/without power difference (-P) between or among the participants, and it is the reflection of deference politeness. Finding of the research shows that symmetrical use of high code in two societies emphasized deference and non-solidary because of no-power difference and social distance. The patterned use of high code, both in the language of Java and Bali, indicates clearly that politeness in hierarchical societies is not merely a communication strategy, but it is a kind of social and lingual agreements between or among the members of the social community as well as the members of lingual community $[1,2,3]$. Using a certain code of communication is the speakers' rights and obligations in hierarchical societies of Java and Bali.
\end{abstract}

Keywords—non-solidary, social deference, deference politeness, non-intimacy, speech level

\section{INTRODUCTION}

Although the local languages of Indonesia have unique speech levels, take two examples the language of Java and Bali with their speech levels, but the studies in Indonesia especially code choices in Javanese and Balinese have not been received serious attention yet, neither from Indonesian linguists nor foreign linguists [1]. Let us say that all the speakers of Javanese and Balinese are monolinguals, but in fact it is apparent that multilingual behavior is not quantitatively different from monolingual [4]. Monolinguals of hierarchical languages of Javanese and Balinese often switch from one code to another code within the same language. Monolingual behavior is not quantitatively different from the behavior of multilingual in using communication code. The difference is, multilingual do switching in languages (from one language to the other one), while monolingual of stratified languages do code switching (from one speech level (high speech level) to another speech level (low speech level, or vice versa). The studies of the use of communication code in Javanese and Balinese so far are mostly not different from the study of code choices in bilingual or multilingual non-stratified language, the languages without speech levels. This study tries to see and to show that the code choice in two languages are not merely shown the same phenomena as phenomena of bilingual/multilingual of the languages without speech levels. Discussing the language of Java and Bali will not be complete enough without discussing the existence of its co-variation, low and high variation. These low and high variations are wellknown for speech levels. Principally there are two speech levels in Javanese and Balinese, i.e. low and high code or low and high speech levels. Low code is a variation with low morpheme and low vocabulary used to fulfill communication need with intimates and or the same status or different status.

Symmetrical use of low speech level reflects no distance among the speakers. But the asymmetrical use of low and high code is an index of inequality between the participants. A sentence in low code in Javanese: Saiki kowe mangan dhisik 'You eat first now' is usually uttered by a person to an addressee who is intimate enough or uttered by a superior to a subordinate. An older speaker has a right to speak low code to children. Between intimate friends it is allowed to use low code to each other. High code or high variation of the language of Java, is best described as a variation with high code morpheme and high code or vocabulary used to communicate with nonintimates and or to higher status or superior. It is a kind of social agreement for speakers of the language of Java and also in the language of Bali to employ high speech level, high code, when speaking to non-intimate participant [1, 2, 3]. Young speakers of Javanese are also obligated to use high code when speaking to older speakers of Javanese $[1,2,3]$.

The researchers purposely use of the term code choice in two languages, Javanese and Balinese, which are hypothetically uncovered by the theory which is usually used to analyze European languages that do not recognize what is wellknown in Javanese and Balinese i.e. speech levels. By 
focusing on code choice in Javanese and Balinese, it is intentionally to see whether there is another phenomenon we could find from the code use in Javanese and Balinese. By considering the use of $\mathrm{H}$ (igh) code and $\mathrm{L}(\mathrm{ow})$ code within two languages of Javanese and Balinese, the researchers try to see more into the phenomena of code use in them. It is undebatable to research the language of Java and Bali without paying attention to their speech levels, low and high speech levels, will become incomplete. Because of the existence of its speech levels, the language of Java is finally classified as the most elaborate language in the world $[4,5,6]$. It was honestly admitted that "Javanese way of showing intimacy by means of language is much more elaborate than any examples in European languages" which only have terms of address (T/V) and even the languages known in the world as stated above [4-10]. Let us begin the discussion by taking a short talk in the Javanese language executed by a boss and her maid-servant who is working in this family.

Text 1

(1) Boss: Saiki kowe nggoreng iwak laut wae yo! /Now you fry some fish, will you?

(2) Servant: INGGIH, BU. (NANGING) KULO BADHE TUMBAS SAREM RUMIYIN.

/Alright madam, (but) I'll buy some salt first/

The above conversation is a dialog between a boss and her maid servant occurred in a family of Java. The boss, as shown in the dialogue, will always deliver her instruction to her maid servant using low code or low speech level of the language of Java but on the other hand, her maid servant, will always respond, deliver her speeches and her wishes in high code of speech level of the language of Java before her boss, as seen in line two (2) of Text 1.

The above illustration presents different phenomena of code using of two different codes, namely H(igh) code and L(ow) code of Javanese language. If we look at the above dialog (Text 1) using the theory of code (code-switching), in fact, we cannot identify whether the above phenomena of code choice is code-switching or code-mixing. Both speakers, in the above conversation (Text 1), always use two different or opposite codes (the boss uses L(ow) speech level and the maid servant uses $\mathrm{H}(\mathrm{igh})$ speech level (high code)) when talking to each other from the beginning to the end of the conversation. The boss always and will always use low speech level of Javanese, while on the other hand, the maid servant will always use high speech level of Javanese (high code) to express her ideas and intentions to her boss.

If the conversation is repeated whenever, wherever, and in any topic, as far as the participants are of the same social level as a boss and servant, so the phenomena of code choices will be the same: the boss uses (L)ow code and her maid servant uses $(\mathrm{H})$ igh code. It is seen that the code choice and code using as shown in the Text 1 is not fully covered by the theory of code (code-switching and code-mixing) we have known so far. The first speaker (boss) and the second speaker or the interlocutor (maid servant) in the above conversation, do not do code-switching neither code-mixing. Both speakers in the utterance (1) and (2), always choose two fundamentally different codes - the code which categorized into different speech levels in Javanese language. Let us have another example below.

\section{(3) DALEM BADHE nedha SAMENIKO (I'll eat right} now).

The researchers intentionally present the above statement in capital italic to refer to high speech level of Javanese, and the verb nedha 'eat' is presented in low italic to refers to middle speech level of Javanese. The word DALEM, BADHE, and SAMENIKA are High speech level (high code), but nedha is middle speech level of Javanese (madya). As a whole the statement 'DALEM BADHE nedha SAMENIKO' refers to $\mathrm{H}$ (igh) speech level of Javanese (high code). The above example (5), shows us the phenomena of code mixing within one language, namely $\mathrm{H}$ (igh) code (high code) and $\mathrm{M}$ (idle) code (madya) of Javanese appear in an utterance. It refers to intra-sentential code-mixing. We have to underline that the code-mixing in the example appears within one language, namely Javanese. Speech level is speech variation or language variation which can be or usually used to show intimacy, deference, and hierarchy among the members of society, both in formal or informal communication, both written or spoken forms, both in formal or non-formal situation [1]. Politeness is a social contract i.e. an acknowledgment of the existence of low and high social classes which is implemented in communication contract using speech levels which are appropriate according to status scale and social distance scale based on the participants' rights and obligations in order to keep social harmony [1, 2, 3]. System is "a set of connected items or devices which operated together" [13]. The items in politeness are form of an utterance, context, participants, and the effect of the utterance [14]. Speech or language community is a group of people who use language code which is acceptable and understood as communication media of daily life, both spoken and written communication, both formal and informal communication in line with social rules [1, 2, 3].

Terms of address (T/V) Terms of address or "address forms are the words speakers use to designate the person they are speaking to while they are talking to them" [11]. According to Bonvillain [15] terms of address "may be personal names, titles, kinship terms, or personal pronouns that can be used separately or concomitantly". There are two main kinds of terms of address: names and second-person pronouns. Term of address is part of a complete meaning system used in social relationship. Brown and Gilman [11] investigated the use of terms of address in French, German, and Spanish. They stated that the use of terms of address was governed by two semantic meanings called power and solidarity. Power pronoun semantic as power relation, is non-reciprocal. Someone has power over the other in the degree that he is able to control another behavior. This relationship is non-reciprocal since two persons are not able to have power on the same area. On the same way, power semantic drives a speaker to use non-reciprocal term of address. Inferior uses $\mathrm{V}$ to superior, but inferior receives $\mathrm{T}$ 
from superior. Diglossia is the language situation in which two languages or two variations of a language (called (H)igh variation and (L)ow variation) have different functions within a society [16]. The situation of diglossia will exist in a certain society if there are two different codes which show clear different functions; i.e., one code is used in a set of situation and the other code is used in a situation which entirely different.

The next table of matrix [17, 18], and it was modified by researchers, presents four situations of speech community: (a) bilingual as well as diglossia $(+\mathrm{Bi},+\mathrm{Di})$, (b) bilingual without diglossia (+Bi, -Di), (c) monolingual with diglossia $(-\mathrm{Bi},+\mathrm{Di})$, and (d) monolingual without diglossia (-Bi, -Di). Fishman [19] and Romaine [18] stated that diglossia is different from bilingualism. That is why diglossia and bilingualism have to be carefully differed $[18,19]$.

deference and

\section{TABLE I BILINGUALISM AND DIGLOSSIA}

\begin{tabular}{|c|c|c|c|}
\hline \multicolumn{2}{|c|}{} & \multicolumn{2}{c|}{ Diglossia } \\
\cline { 3 - 4 } \multicolumn{2}{|c|}{} & + & - \\
\hline \multirow{3}{*}{ Bilingualism } & + & $+\mathrm{Bi}$ & $+\mathrm{Bi}-$ \\
& + & $+\mathrm{Di}$ & $\mathrm{Di}$ \\
\cline { 2 - 4 } & - & $-\mathrm{Bi}+\mathrm{Di}$ & $-\mathrm{Bi}-\mathrm{Di}$ \\
\hline
\end{tabular}

Example:

$+\mathrm{Bi},+\mathrm{Di}$ : Paraguay (Spanish and Guarani)

$+\mathrm{Bi}$, - Di: Belgium (German and French)

$-\mathrm{Bi},+\mathrm{Di}$ : Russian

-Bi, -Di : Hypothetical

Scollon and Scollon [20] offer three politeness systems called solidarity politeness system, deference politeness system, and hierarchical politeness system. First, solidarity politeness system is described when two close friends have a conversation will show face solidarity. There is not any feeling and power difference (-P) and distance (-D) between the participants. Someone can find solidarity politeness anywhere the system is egalitarian and the participants feel or express closeness each other. Friendship between close colleagues is often in solidarity politeness. Second, deference politeness system is politeness in which the participants are considered to be equal or nearly equal but they treat each other in distance. Scollon and Scollon [20] illustrate if a university professor named Dr Wong from Hong Kong meets a university professor from Tokyo name Dr Hamada, they are likely to refer to each other as "Professor Wong" and "Professor Hamada". Third, hierarchical politeness system in which the participants know and appreciate social differences which put someone in higher position or superordinate and the other as a subordinate. This is a face system where Mr. Hutchin (boss) speaks 'downward' to his employee (Bill) and Bill speaks 'upward' to his boss (Mr Hutchin) [20]. Holmes [10] identified that the code choice is influenced by the social factor and the social dimension. Social factor refers to the participants (the user of the language). The other factor refers to the use of the language: social setting and interaction function. Holmes [12] also put WHO is talking to WHOM (e.g. superior-inferior, boss-servant, customer-servant) as social factor which is important to determine code choice. Social scale and status scale are relevant enough to measure the degree of politeness. Social distance scale is useful to measure how well someone knows his or her interlocutor. Social distance scale is illustrated as follows [see 1, 2, 3].

\section{Intimate Distant \\ High solidarity Low solidarity}

Fig. 1 Social Distance Scale

\section{RESEARCH METHOD}

In order to collect the data for the research, the researchers themselves were the key instruments during the research. The researchers went into the community in order to observe how the speech levels of the two languages, Javanese and Balinese, are used by the members of two social and speech communities in a speech event. The researchers also used a recorder to aid recording during data collection. Cell-phone conversation became the best way of recording in data collection. It was clear enough to identify who was speaking to whom, and how the interlocutor responded (using what speech levels). The data collection was done through collecting short messages on cellphone also. The data collection through document study (the novel of Java and Bali) was done through the following steps. First, the researchers read by using a scanning technique. Second, the process of identification of the dialog in which the participants both use high code of speech levels. Third, the researchers re-transcribe the dialog in order to present the data in written form.

\section{RESULTS AND DISCUSSIONS}

The discussion, analysis, and interpretation include how the speech levels of Javanese are used and employed by its speakers to fulfill daily need of communication and interaction The discussion here will only include symmetrical exchanges of high code, the function and the meaning of the use of high code, and politeness reflected in the use of high code.

\section{A. Symmetrical use of High code}

This discussion presents a short dialog executed by two speakers (P1 and P2), the speakers of the language of Java, both are using high speech level of Javanese, high code. The transcription is in italic capital to emphasize that the code is in high speech level, a high code of communication in the language of Java.

Text 2

(01) M: KATHAH KAMBANGANIPUN PAK? 
many the ducks Sir? How many ducks have you got, Sir?

(02) A: NAMUNG SEKEDHIK. TIGANG DASA

only a few. thirty

They are only thirty (ducks)

(03) M: TIGANG DASA KAMBANGAN MENAWI NIGAN

Thirty ducks if have

eggs

BIASANIPUN PINTEN?

usually how many?'

If there are thirty ducks, how many eggs will have?

(04) A: NGGIH KADANG SELANGKUNG

Yes sometimes twenty-five

'Yes, sometimes twenty-five

(04) M: SELANGKUNG NGGIH KATHAH

Twenty-five yes many

Twenty-five are large enough

(05) A: MENIKA NGGIH TERGANTUNG KALIYAN

This yes depend on

PAKANIPUN. MENAWI PAKANIPUN SAE

the seed. if the seed $\operatorname{good}$

NGGIH TIGANIPUN SAE

yes the egg good

It depends on the seed. If the seed is good, their eggs

will be good too.

A short dialog above presents how the participants employ high code to each other. Since their local language is Javanese, they express their ideas in their mother tongue namely the language of Java. As it is stated above that the language of Java could not be separated from its speech levels, low and high speech level. Therefore it is usual for the speakers of the language of Java to use low or high code in their communication, both in formal or informal communication.

All the utterances done by two participants in Text 2 are expressed in high speech level of the language of Java called krama or basa. Of course, symmetrical use of high code is not temporary, but it is permanently. One two participants involve in a dialogue and they choose high speech level of Javanese called high code to communicate to each other, they will maintain it for ever. It does not mean that they use a high code just for today, in a certain speech event, and next time they will change it into ngoko 'low code' of Javanese. Once more, once they use high code to speak to each other, they will use it for ever, as far as they speak in the language of Java.

The following dialog shows how two participants employ high code of Balinese to convey their ideas to each other. It means that the phenomena of the use of high speech levels is easily found also in the language of Bali. It is usual for the speakers of Javanese and Balinese to use low and high codes of their language every time they communicate to the members of the societies. Since they have two communicative codes, low and high code, they will always use them based on the social relationship between or among them. When they consider that they have the same social status and they are intimate enough, the code they have to use is based on the social agreement, namely low code in their languages. On the other hand, when they have the same social status but they are not intimate enough, they will use high code to express their feeling and ideas during their social communication and lingual communication.

Text 3 [21]

(1) Fisherman 1: Pak Polisi, PUNAPI RARIS ANAKE SANE RURUH Bapak?

/Policeman. How is the child that you are looking for?/

(2) Policemen : YIIH JAKTI. KADUNG KELANGEN TIYANG MIRAGIANG BAOS BAPAKE SARENG KALIH. TIYANG NGRURUH ANAK BAJANG SANE LAPORANGA OLIH RERAMANNE. KOCAP IPUN NILARIN UMAH TANPA PAMIT, KATARKA MINGGAT SARENG GELANNE.

/Yes, right. I have already fascinated listening to the words of the two of you. I'm looking for a young woman reported by her parents. He said she ran away from her house, it seemed she was running away with her boyfriend/.

(3) Fisherman 2: DADOS BAPAK NGRURUH KA TONGOSE SUWUNG SAMUN SEKADI PUNIKI?

/Why are you looking for her in a quiet place like this?/

(4) Policeman: BIASANNE, ANOM-ANOME SANE SEDEKAN KASMARAN, TEN MILIH GENAH, KEWALA ILID PANINGALANNE, JEG KANGGO. BUINA TIYANG POLIH NUDUK PAKAIAN ANYUD WAWU, NYANGKET RING TELABAHE

/Young people who are in love usually don't choose places, what is important is that the place is hidden, no one sees it, okay. Besides, I just picked up clothes that were washed away, stuck in the river/

\section{B. Marker of Social Distance $(+D)$}

As it was stated above that all the participants in Text 2 and Text 3 employ the utterances and expressions in high code of communication. Why do they choose and utterances high code as a means of communication? Why do they use high speech level as a means of communicating their thinking, feeling, and idea to their interlocutors? Why do not they choose low speech level or low code which is also available in the language of Java and Bali? Is it an accidental or do they use high code randomly? Is there any well-planned motivation by all participants to do so? If it is a well-planned activity to use high code, the question is what factor drove and motivated 
them to choose and to use high code? What factors motivate them to choose and to use high speech level? It is impossible by the use of a certain linguistic code without being driven by a certain factor. What for do participants use high code if there is not any factor which drives them to do so? What is the function and the meaning of the use of high code by all participants involve in a speech event in a speech community?

The speakers of Javanese and Balinese consciously control every activity in using their speech levels in their languages. The factor of social distance drives the participants to use high code during their social activities. High speech levels that they choose and use are functioned as a medium of deferring each other because of social distance between the participants. Social distance is symbolized by $(+\mathrm{D})$, plus distance. In other word, the use of high code is functioned as non-intimacy marker by the participants because of social distance.

\section{Marker of Equality (-P)}

Mainly in dyadic communication using high code also refers to equality, but there is a difference that should be explained. Symmetrical use of low code in Javanese and Balinese refers to equality and intimacy, but symmetrical use of high code refers to equality in distance or equality minus intimacy. When two speakers use low code, they develop equality between them but they treat each other in the distance. The use of high code is to show equality in distance. Equality is symbolized by $(-\mathrm{P})$, minus power, but equality in distance is symbolized by $(+\mathrm{D})$, plus distance, that is why the participants use high code, not low code as seen in Text 2 and 3. Equality which is symbolized by (-P) 'minus power' means that there is no power difference between the participants. Participants involve in a speech event in a speech community treat each other as in the same social status. Although they treat each other in equality, without any power difference, but they are in social distance. Social distance is symbolized by $(+D)$ 'plus distance'. Plus distance $(+D)$ could mean without intimacy, they are socially in the same status, but they are in social distance. Social distance $(+D)$ is dominantly influenced the symmetrical use of high code.

The use of high code is a reflection politeness called deference politeness. Each participants defer each other, their own interlocutor by choosing and using high code. Is it only high code utterances that could be used to show "true" politeness in Javanese and Balinese? If the use of low code is identified as solidarity politeness, so the use of high code is called deference politeness. When the participants use high code for the all category of words, it is identified as deference politeness shown by the participants. Text 2 or 3 is an example of a dialog between two speakers in which they use deference politeness system. Deference politeness system is politeness in which the participants are equal or nearly equal but they treat each other in distance $(+\mathrm{D})$. The characteristic of deference politeness is (1) equal (-P), namely the participants seen themselves in an equal position and they use high code to each

other; (2) distance (+D), namely they treat themselves in the distance. Deference politeness system in Javanese is illustrated below [1].

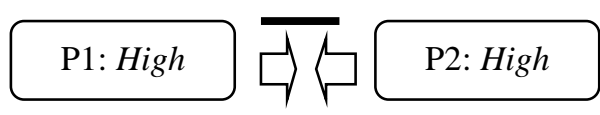

Fig 3.1

Deference Politeness in Javanese and Balinese

A black line above two arrows, as shown in Figure 3.1, is a symbol of high code of speech level, and a pair of face to face arrow symbolizes social equality between the participants involve in social and lingual communication. By the time the participants define themselves to be socially equal but not intimate, they will develop deference politeness anywhere and any time. Setting (place, time, and situation (both formal or informal)) do not tend to influence deference politeness in a stratified society, such as in the society of Java and Bali. Once they or the participants use high code to speak to each other, they will use high code forever every time they speak to each other. Symmetrical use of high code is an index of deference. When two speakers use high code to speak to each other, it is identified as deference politeness. The relationship between two non-intimate friends which is implemented by using high code to speak to each other during their daily life is really a reflection of politeness. The marker of equality is symbolized by (-P) 'minus power' and non-intimacy (+D) 'plus distance'. They mean that there is no power difference between the participants and there is social distance between the participants. Social distance here means that the participants treat each other in distance or in non-intimate relationship. They express their equality but non-intimacy by using high speech levels of Javanese, high code. They also would like to show their respect and their politeness to each other, so high speech level (high code) becomes the best choice for them to express their politeness in language use.

\section{CONCLUSION}

The description of the use of high speech level (high code) in two languages of Java and Bali shows three points. Firstly, symmetrical exchanges of a high code, in which the participants make a decision to choose and use high code to communicate everything during their life. Secondly, symmetrical exchanges of high code was used as a marker of equality in distance $(-P ;+D)$, and the meaning is equality but non-intimacy. It can be also as an index of non-solidarity. Thirdly, symmetrical exchanges of high code reflects deference politeness. The communication pattern by using high speech level (high code) which is well patterned, and they supported by two factors, and yield deference politeness, it could be concluded that politeness in Javanese is a kind of "social contract", i.e. there are rights and obligations that have to maintain by the participants. In deference politeness, the 
participants are obligated and it is their rights also to use high speech level (high code) to speak to each other. Fourth, regular use of a certain speech level, in this case high code, in every speech event in a speech community, it can be interpreted that it is not merely a communication strategy, but it is a kind of social contract, in general and wide sense. In a narrower sense, it is a kind of communication contract or communication agreement. Since it is a communication contract, it means that there are rights and obligations between the participants. The rights and as well as the obligations for the participants, in symmetrical non-intimate communication, are to use high speech level (high code) to address each other. If one of the participant, what ever reason, changes high code into the other code, let us say, ngoko, it will happen, of course, communication break down. Changing the code that has to be used accrdingly, it means that one participant breaks the rules and the agreement that should be maintained. It will never happend since every member of the society is responsible for their social harmony through communication agreement and social agreement.

\section{ACKNOWLEDGMENT}

This research was funded by DIPA Grant - Politeknik Negeri Bali and also the researchers would like to express the greatest thanks for the Director, Vice of Director I, II, III and Head of Research Center - Politeknik Negeri Bali for the supports and highly motivation. The authors also would like to express the deepest thank to Directorate of Research and Social Services, General of Research Strengthening and Development, Ministry of Research, Technology and Higher Education of Republic of Indonesia as the sponsor of this research through the scheme of fundamental research grants.

\section{REFERENCES}

[1] Wajdi, M., Laksana, I K. D., Suastra, I M., Budiarsa, I M. Codecrossing: Hierachical Politeness in Javanese. e- Journal of Linguistics, [S.I], feb. 2015. ISSN 2442-7586. 2015. http://ojs.unud.ac.id/index.php/eol/article/view/11196

[2] Wajdi, M and Paulus Subiyanto. Equality marker in the language of bali. Published under licence by IOP Publishing Ltd., 2018. Journal of Physics: Conference Series, Volume 953, conference 1.

[3] Wajdi, M and Paulus Subiyanto. Social and Speech Commnunity of Central Java Indonesia. Advanced Science Letters, Volume 23, Number 12, December 2017, pp. 12172-12176(5), 2007. DOI: https://doi.org/10.1166/asl.2017.10595

[4] Sankoff, G. "Language Use in Multilingual Societies: Some Alternative Approaches", in Pride J.B. dan Janet Holmes. eds.. 1974 (?). Sociolinguistics: Selected Readings. Penguin Education, New York (?), 1974.

[5] Berman, L. A. Speaking Through the Silence: Narratives, Social Conventions, and Power in Java. Oxford University Press, New York, 1998.

[6] Keeler, W. 1987. Javanese Shadow Plays, Javanese Selves. Princeton, N.J.: Princeton University Press.

[7] Smith-Hefner, N. Women and politeness: The Javanese example. Language in Society, Vol. 17, 535-554. 1988.

[8] Geertz, C. Abangan, Santri, Priyayi Dalam Masyarakat Jawa. Diterjemahkan oleh Aswab Mahasin. Jakarta: Pustaka, Jakarta, 1981.

[9] Fasold, R. Sociolinguistics of Language. USA: Basil Blackwell Inc, USA, 1960

[10] Hudson. R.A. Sociolinguistics. Cambridge University Press. New York, 1982.

[11] Brown, R. dan A. Gilman. "The Pronoun of Power and Solidarity", in Sebeok, T.A. ed. Style In Language. MIT Press, 1960.

[12] Holmes, J. An Introduction to Sociolinguistics. England: Pearson Education Limited, England, 2001.

[13] Cambridge Advanced Learner's Dictionary (CALD - CD ROOM). Cambridge University Press, 2003

[14] Thomas, J. Meaning in Interaction: An Introduction to Pragmatics. England: Longman Group Limited, England, 1995.

[15] Bonvillain, N. Language, Culture, and Communication: The Meaning of Messages. New Jersey: Pearson Education Inc, New Jersey, 2003.

[16] Wardhaugh, R. An Introduction to Sociolinguistics. Blackwell Publishing, USA, 2004.

[17] Fishman, J.A. "Bilingualism with and without Diglossia; Diglossia with and without Bilingualism". Journal of Social Issues 23: 29-38. 1967.

[18] Romaine, S. Bilingualism. USA: Blackwell Publishers, USA, 1995

[19] Fishman, J.A. "Bilingualism and Biculturalism as Individual and Societal Phenomena". Journal of Multilingual and Multicultural Development 1:3-17. 1980.

[20] Scollon, R and Suzanne Wong Scollon. Intercultural Communication: A Discourse Approach. Basil Blackwell Ltd, UK, 2001.

[21] Ardhi, A.W.S. Sandiwara Mabhasa Bali: Bogolan. Arti Foundation, Denpasar, 2015. 